\title{
Mechanisms of Hypochlorite Injury of Target Cells
}

\author{
Ingrid U. Schraufstätter, Ken Browne, Anna Harris, Paul A. Hyslop, Janis H. Jackson, \\ Oswald Quehenberger, and Charles G. Cochrane \\ Department of Immunology, Research Institute of Scripps Clinic, La Jolla, California 92037
}

\begin{abstract}
$\mathrm{HOCl}$, which is produced by the action of myeloperoxidase during the respiratory burst of stimulated neutrophils, was used as a cytotoxic reagent in P388D1 cells. Low concentrations of HOCl (10-20 $\mu \mathrm{M})$ caused oxidation of plasma membrane sulfhydryls determined as decreased binding of iodoacetylated phycoerythrin. These same low concentrations of $\mathrm{HOCl}$ caused disturbance of various plasma membrane functions: they inactivated glucose and aminoisobutyric acid uptake, caused loss of cellular $\mathrm{K}^{+}$, and an increase in cell volume. It is likely that these changes were the consequence of plasma membrane SH-oxidation, since similar effects were observed with para-chloromercuriphenylsulfonate ( $p C M B S)$, a sulfhydryl reagent acting at the cell surface. Given in combination pCMBS and HOCl showed an additive effect.

Higher doses of $\mathrm{HOCl}(>50 \mu \mathrm{M})$ led to general oxidation of -SH, methionine and tryptophan residues, and formation of protein carbonyls. HOCl-induced loss of ATP and undegraded NAD was closely followed by cell lysis. In contrast, NAD degradation and ATP depletion caused by $\mathrm{H}_{2} \mathrm{O}_{2}$ preceded cell death by several hours. Formation of DNA strand breaks, a major factor of $\mathrm{H}_{2} \mathrm{O}_{2}$-induced injury, was not observed with $\mathrm{HOCl}$.
\end{abstract}

Thus targets of $\mathrm{HOCl}$ were distinct from those of $\mathrm{H}_{2} \mathrm{O}_{2}$ with the exception of glyceraldehyde-3-phosphate dehydrogenase, which was inactivated by both oxidants. (J. Clin. Invest. 1990. 85:554-562.) hypochlorite toxicity • plasma membrane protein oxidation • sulfhydryls

\section{Introduction}

When neutrophils are stimulated they release oxidants that serve as antimicrobial weapons but at the same time may cause injury of the surrounding tissue (1-4). Both $\mathrm{H}_{2} \mathrm{O}_{2}(5-8)$ as well as neutrophil derived proteases $(9,10)$ have been shown to induce injury in various target cells. $\mathrm{HOCl}$ formed from $\mathrm{H}_{2} \mathrm{O}_{2}$ by the action of myeloperoxidase has similarly been shown to be cytotoxic $(11,12)$. Because a minimum of $25-40 \%(13,14)$ of the $\mathrm{H}_{2} \mathrm{O}_{2}$ formed by stimulated human PMNs is halogenated into $\mathrm{HOCl}$, it seemed important to define the mechanisms involved in $\mathrm{HOCl}$-induced impairment of cell function.

Bacteria exposed to $\mathrm{HOCl}$ are killed within milliseconds after the addition of the oxidant $(15,16)$. Inhibition of bacterial membrane transporters (17) as well as damage to their

Address reprint requests to Dr. Schraufstätter, Department of Immunology, IMM 12, Research Institute of Scripps Clinic, 10666 North Torrey Pines Road, La Jolla, CA 92037.

Received for publication 20 April 1989 and in revised form 8 September 1989.

J. Clin. Invest.

(C) The American Society for Clinical Investigation, Inc.

0021-9738/90/02/0554/09 \$2.00

Volume 85, February 1990, 554-562 respiratory enzymes $(18,19)$ have been described as possible pathways for $\mathrm{HOCl}$-mediated bacterial killing. Although a number of biochemical targets of $\mathrm{HOCl}$ are known (thioethers, amino-, heme-groups, etc.) (20-23), the pathways leading to cell injury in mammalian cells are poorly understood. The current studies were therefore undertaken to define the biochemical targets of $\mathrm{HOCl}$ and to analyze the effect of their oxidation on cellular functions.

\section{Methods}

Cell culture. $\mathrm{P} 388 \mathrm{D} 1$ murine macrophage-like tumor cells were grown in RPMI 1640 as previously described (24). The cells were centrifuged at $400 \mathrm{~g}$ for $5 \mathrm{~min}$, washed two times in modified Gey's buffer (MGB, ${ }^{1}$ $147 \mathrm{mM} \mathrm{NaCl}, 5 \mathrm{mM} \mathrm{KCl}, 1.9 \mathrm{mM} \mathrm{KH}_{2} \mathrm{PO}_{4}, 1.1 \mathrm{mM} \mathrm{Na}_{2} \mathrm{SO}_{4}, 5.5$ mM glucose, $1.5 \mathrm{mM} \mathrm{CaCl}_{2}, 0.3 \mathrm{mM} \mathrm{MgSO}_{4}$, and $1 \mathrm{mM} \mathrm{MgCl}_{2}, \mathrm{pH}$ 7.4), and resuspended in that buffer at a concentration of $4 \times 10^{6}$ cells $/ \mathrm{ml}$. To avoid high local concentrations of $\mathrm{HOCl}, \mathrm{HOCl}$ was added to MGB, immediately followed by the addition of cells to a final concentration of $2 \times 10^{6} \mathrm{cells} / \mathrm{ml}$. All experiments were performed at $37^{\circ} \mathrm{C}$. In some experiments MGB was replaced with $150 \mathrm{mM}$ choline chloride (Calbiochem-Behring Corp., La Jolla, CA), $5.5 \mathrm{mM}$ glucose, $\mathrm{pH} 7.4$.

Cell lysis was determined by trypan blue exclusion or LDH release.

Preparation of $\mathrm{HOCl}$. NaOCl (Mallinckrodt, Inc., St. Louis, MO) was adjusted to $\mathrm{pH} 7.4$ with $\mathrm{H}_{2} \mathrm{SO}_{4}$. The sum of $\mathrm{HOCl} / \mathrm{OCl}^{-}$was quantified by assuming an extinction coefficient of $e_{235}=100 \mathrm{M}^{-1}$ $\mathrm{cm}^{-1}$ for $\mathrm{HOCl}$, which accounts for $50 \%$ at the $\mathrm{pH}$ of 7.4 (16) or by iodometric titration (14).

Determination of protein sulfhydryls and disulfides. $2 \times 10^{6}$ cells were exposed to $\mathrm{HOCl}$ for $15 \mathrm{~min}$ and then processed for sulfhydryl determination as follows.

Cellular protein was precipitated with $400 \mu 150 \%$ TCA, samples were left on ice for $10 \mathrm{~min}$, microfuged for $1 \mathrm{~min}$, and washed twice with $7 \%$ TCA. For reduced sulfhydryl determination, the precipitate was resuspended by sonication in $2 \mathrm{M}$ guanidine thiocyanate, $500 \mathrm{mM}$ Tris, 10 mM EDTA, pH 7.6, $100 \mu \mathrm{M}$ dithionitrobenzoic acid (DTNB; Sigma Chemical Co., St. Louis, MO) $(25,26)$; sulfhydryls reduce DTNB forming yellow colored TNB. Alternatively, resuspension was in $2 \mathrm{M}$ guanidine thiocyanate, $50 \mu \mathrm{M}$ glycine, $100 \mathrm{mM}$ sodium sulfite, $3 \mathrm{mM}$ EDTA, $100 \mu \mathrm{M}$ 2-nitro-5-thiosulfobenzoate (NTSB), pH 9.5 (27). The sulfite cleaves disulfide bonds, such that the sum of -SHs and disulfides is measured by reduction of NTSB.

The samples were incubated for $25 \mathrm{~min}$ at room temperature and the $\mathrm{OD}_{415 / 550} \mathrm{~nm}$ was measured on titertek plates on $200-\mu \mathrm{l}$ aliquots (Autoreader, EL 310; Biotek, Inc., Burlington, VT). Molarities were calculated assuming an extinction coefficient of $e_{415}=12,200 \mathrm{M}^{-1}$ $\mathrm{cm}^{-1}$ for TNB.

Disulfides were calculated as the difference between the two determinations.

Determination of extracellularly accessible sulfhydryls. For ${ }^{203} \mathrm{Hg}$ $p C M B S$ binding, $2 \times 10^{6}$ cells/ml were incubated with $5 \mathrm{nmol} p C M B S$

1. Abbreviations used in this paper: Di-O- $\mathrm{C}_{5}, 3,3^{\prime}$ dipentyloxacarbocyanine; DOG, 2-deoxyglucose; DNTB, dithionitrobenzoic acid; GAPDH, glyceraldehyde-3-phosphate dehydrogenase; I-PE, iodoacetylated phycoerythrin; MGB, modified Gey's buffer; MPO, myeloperoxidase; NTSB, 2-nitro-5-thiosulfobenzoate; poly-ADPRP, polyADP-ribose polymerase; $p$ CMBS, $p$-chloromercuriphenylsulfonate. 
containing $50 \mathrm{nCi}{ }^{203} \mathrm{Hg}$-pCMBS (Amersham Corp., Arlington Heights, IL; $10-100 \mathrm{mCi} / \mathrm{g} \mathrm{Hg}$ ). After a 5 -min incubation at $37^{\circ} \mathrm{C}$, $200-\mu$ l aliquots of cell suspension were centrifuged through silicone oil as described for amino acid uptake. $p C M B S$ as a charged molecule (28) does not penetrate into uninjured cells.

Since $p C M B S$ binding is affected by plasma membrane permeability changes, a larger size sulfhydryl reagent was needed to quantify extracellular - $\mathrm{SH}$ groups in $\mathrm{HOCl}$ damaged cells: iodoacetylated $\mathrm{R}$ phycoerythrin (I-PE, mol wt 240,000; Molecular Probes, Eugene, OR) was used for this purpose. $1 \times 10^{6} \mathrm{P} 388 \mathrm{D} 1$ cells $/ 500 \mu \mathrm{l}$ MGB were incubated with $\mathrm{HOCl}$ for $10 \mathrm{~min}$ at $37^{\circ} \mathrm{C} .5 \mu \mathrm{l} 0.5 \mathrm{M}$ Tris, $\mathrm{pH} 8.5$ was added to bring the $\mathrm{pH}$ to 7.9 , followed by $11.1 \mu \mathrm{g} / \mathrm{sample}$ of I-PE. This concentration of phycoerythrin label had been titrated to yield maximal binding. The cells were incubated for $30 \mathrm{~min}$ at room temperature, and phycoerythrin binding was determined by FACS analysis (FACS IV, Becton Dickinson Co., Mountain View, CA) using rhodamine filters. To subtract background fluorescence, cells were exposed to 16 $\mathrm{mM} \beta$-mercaptoethanol before the addition of I-PE, which completely prevented labeling of the cells.

Glutathione determination. Total and oxidized glutathione were determined as previously described except that the samples were assayed on microtitertek plates (29). GSH was calculated as the difference between the two determinations.

Determination of protein methionine sulfoxide formation. P388D1 cells were labeled with $10 \mu \mathrm{Ci}\left[{ }^{35} \mathrm{~S}\right]$ methionine $(600 \mathrm{Ci} / \mathrm{mmol}$; New England Nuclear, Boston, MA) for $18 \mathrm{~h}$. After two washes in MGB, the cells were exposed to $\mathrm{HOCl}$ for $15 \mathrm{~min}$ at $37^{\circ} \mathrm{C}$, and protein was precipitated by TCA. The samples were boiled for $10 \mathrm{~min}$, microfuged, and washed twice with TCA to remove free methionines. Cell precipitates were solubilized in $70 \%$ formic acid and digested with $30 \mathrm{mM}$ cyanogen bromide for $20 \mathrm{~h}$. Cyanogen bromide cleaves proteins at methionine residues forming volatile isothiocyanate, whereas oxidized methionine is not reactive with cyanogen bromide. ${ }^{35} \mathrm{~S}$-label was determined before and after removing $\left.{ }^{35} \mathrm{~S}\right]$ isothiocyanic acid by volatilization under $\mathrm{N}_{2}$, and label in methionine was calculated from the difference. Label in methionine sulfoxide was calculated from the amount of label that was not volatilized (20).

Determination of tryptophan fluorescence. Cells were TCA precipitated as described for sulfhydryl determination, solubilized in SDS, and fluorescence (280 nm excitation, $345 \mathrm{~nm}$ emission) (30) was determined on a fluorometer (Perkin-Elmer Corp., Norwalk, CT). Tryptophans were quantitated by comparison with a bovine albumin standard, assuming 2 tryptophans/albumin molecule.

Determination of protein carbonyls. Protein carbonyls were determined as described by Starke et al. (31) except that whole cell sonicate rather than only the supernatant fraction was TCA precipitated. In this assay dinitrophenylhydrazine forms hydrazone products with aldehydic protein groups.

Determination of amino acid uptake. $\left[{ }^{3} \mathrm{H}\right]$ aminoisobutyric acid was used as a nonmetabolized amino acid analogue. Cells were exposed to $\mathrm{HOCl}$ for $15 \mathrm{~min}$, microfuged, and resuspended in $10 \mu \mathrm{M}$ aminoisobutyric acid containing $2 \mu \mathrm{Ci}\left[{ }^{3} \mathrm{H}\right]$ aminoisobutyric acid (New England Nuclear) and incubated for $30 \mathrm{~min}$ at $37^{\circ} \mathrm{C} .200-\mu \mathrm{l}$ cell aliquots were microfuged through $150 \mu$ silicone oil (four parts Dow Corning 550, one part Dow Corning 200; Dow Corning Co., Midland, MI) into $10 \mu \mathrm{l}$ $0.5 \mathrm{M}$ sucrose. The cell pellets were scintillation counted. The same procedure was followed for $\left[{ }^{3} \mathrm{H}\right]$ leucine uptake, replacing aminoisobutyric acid with leucine and stopping the incubation with label at $8 \mathrm{~min}$

Measurement of glucose transporter activity. Glucose transporter activity was determined with $\left[{ }^{3} \mathrm{H}\right] 2$-deoxyglucose \pm cytochalasin B in the presence of $100 \mu \mathrm{M}$ glucose as previously described (32).

Determination of cell volume. $\mathrm{P} 388 \mathrm{D} 1$ cells were exposed to $\mathrm{HOCl}$ for various periods of time, $10 \mu \mathrm{g} / \mathrm{ml}$ propidium iodide were added, and the cell volume/viability was determined on a FACS analyzer using a $75-\mu \mathrm{m}$ orifice with a current setting of $0.71 \mathrm{~mA}$ for the volume measurement. The cell volume was assessed by calibration against 4.4-, 6.0-, 9.0-, and 15.67- $\mu \mathrm{m}$ diam beads (Microbeads; Coulter, Hialeah, FL).
${ }^{3} \mathrm{H}_{2} \mathrm{O}$ space was determined as previously described (32).

Measurement of cellular ion content and fluxes. Total cellular $\mathrm{K}^{+}$, $\mathrm{Na}^{+}$and $\mathrm{Ca}^{2+}$ content were determined by atomic absorption as previously described (33).

Cellular $\mathrm{Na}^{+}$content was measured with the fluorescent probe SBFI-AM (34) ( $1 \mathrm{mM}$ in DMSO; Molecular Probes). $1 \times 10^{7}$ cells $/ \mathrm{ml}$ of P388D1 cells were incubated with $10 \mu \mathrm{M}$ SBFI-AM for $30 \mathrm{~min}$ at $37^{\circ} \mathrm{C}$. After two washes in MGB, $2 \times 10^{6} \mathrm{cells} / \mathrm{ml}$ were incubated with $\mathrm{HOCl}$ for $30 \mathrm{~min}$ at $37^{\circ} \mathrm{C}$. SBFI fluorescence ratios were determined on a fluorometer (650-15; Perkin-Elmer) with excitation at 340 and $380 \mathrm{~nm}$ and emission at $510 \mathrm{~nm}$. Free SBFI and various ratios of MGB and its $\mathrm{Na}^{+}$-free $\mathrm{K}^{+}$equivalent were used for calibration.

$\mathrm{K}^{+}$efflux was determined with ${ }^{86} \mathrm{Rb}$ (New England Nuclear). 100 $\mu \mathrm{Ci}{ }^{86} \mathrm{Rb}$ was added to a $150-\mathrm{ml}$ flask of P388D1 cells $24 \mathrm{~h}$ before harvest. The cells were centrifuged at $4^{\circ} \mathrm{C}$, washed twice with MGB at $4^{\circ} \mathrm{C}$, and used immediately. They were incubated at $37^{\circ} \mathrm{C}, 200-\mu \mathrm{l}$ aliquots were layered over silicone oil (see above), and microfuged for $30 \mathrm{~s} ; 100 \mu \mathrm{l}$ of supernatant as well as of cell suspension were counted in a scintillation counter.

Preparation of plasma membranes. $10^{8}$ cells were exposed to various concentrations of $\mathrm{HOCl}$ for $15 \mathrm{~min}$, the cells were centrifuged and resuspended in $5 \mathrm{ml} 0.34 \mathrm{M}$ sucrose, $10 \mathrm{mM}$ Hepes, $1 \mathrm{mM}$ EGTA, 0.1 $\mathrm{mM} \mathrm{MgCl}$, and $1 \mathrm{mM} \mathrm{ATP}$, and kept at $4^{\circ} \mathrm{C}$ throughout the preparation. After $\mathrm{N}_{2}$ cavitation for $15 \mathrm{~min}$ at $600 \mathrm{psi}$, nuclei, and whole cells were removed by centrifugation at $1,000 \mathrm{~g}$ for $10 \mathrm{~min}$. Mitochondria and granules were separated by centrifugation at $10,000 \mathrm{~g}$ for $30 \mathrm{~min}$. The supernatant was then centrifuged at $134,000 \mathrm{~g}$ for $1 \mathrm{~h}$, yielding a crude plasma membrane pellet, and a cytoplasmic supernatant fraction.

Determination of plasma membrane ATPase activity. $50 \mu \mathrm{g}$ plasma membrane protein determined with the BCA reagent (Pierce Chemical Co., Rockford, IL) was incubated with $6 \mathrm{mM} \mathrm{ATP} \pm 0.2 \mathrm{mM}$ ouabain (Sigma Chemical Co.), $\pm 5 \mathrm{mM}$ EGTA for $1 \mathrm{~h}$ at $37^{\circ} \mathrm{C}$. Inorganic $\mathrm{PO}_{4}$ concentrations were determined (35) and compared to a lyophilized $\mathrm{K}_{2} \mathrm{HPO}_{4}$ standard.

Determination of various cellular moieties. ATP and NAD were quantified by HPLC as previously described $(36,37)$. When extracellular nucleotides were determined, the supernatant after removal of the cells by centrifugation was spiked with $\left[{ }^{3} \mathrm{H}\right]$ adenine, the samples were lyophilized, resuspended in $\mathrm{H}_{2} \mathrm{O}$ in $1 / 10$ their original volume, recovery was determined by scintillation counting, and the samples were used in HPLC analysis.

Mitochondrial respiration was measured with a Clark type $\mathrm{O}_{2}$ electrode (32).

Lactate formation was assessed by determination of $\left[{ }^{14} \mathrm{C}\right]$ lactate produced over a 30 -min period at $37^{\circ} \mathrm{C}$ from a medium containing 5 $\mu \mathrm{Ci} / \mathrm{ml} \mathrm{U}\left[{ }^{14} \mathrm{C}\right]$ glucose $(32)$ and $100 \mu \mathrm{M}$ glucose. At the end of this period cells were permeabilized with $0.01 \%$ digitonin, microfuged at $4^{\circ} \mathrm{C}$, and an aliquot of the medium was applied to silica 60 F254 TLC plates (EM Science, Gibbstown, NJ), separated in $\mathrm{H}_{2} \mathrm{O}$ /ethanol/ $\mathrm{NH}_{4} \mathrm{OH}(4: 20: 1)$ (38), and quantitated on the AMBIS beta scanning system (AMBIS Systems, San Diego, CA).

GAPDH and hexokinase activities were determined as described $(32,39)$. When GAPDH activity was determined in pCMBS-treated cells, the cells were washed twice to remove traces of extracellular pCMBS. DNA strand breaks were measured by alkaline unwinding $(37,40)$, and poly-ADP-ribose polymerase activity was measured as TCA precipitable $\left[{ }^{3} \mathrm{H}\right] \mathrm{NAD}$-derived label of digitonin-treated cells $(36,41)$.

Ammonia was determined with a Sigma kit (Sigma Chemical Co.; No. 70-UV).

\section{Results}

\section{HOCl-induced cell lysis}

A dose-response assay of the quantity of $\mathrm{HOCl}$ inducing cell lysis as a function of time is presented in Fig. 1. Doses as low as 


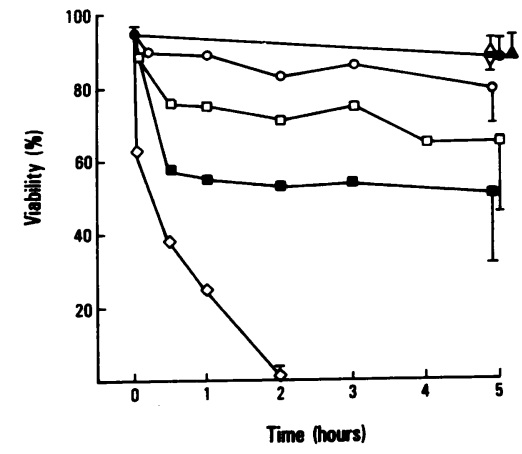

Figure 1. Time-course of cell lysis-as determined by trypan blue exclusion-in $2 \times 10^{6}$ P388D1 cells/ml exposed to various concentrations of $\mathrm{HOCl}$. Mean \pm SD of at least three experiments. For reasons of clearness, SDs are shown for selected time-points only. -, control cells; $\bigcirc, 25$ $\mu \mathrm{M} \mathrm{HOCl} ; \square, 35 \mu \mathrm{M}$

$\mathrm{HOCl} ;=, 50 \mu \mathrm{M} \mathrm{HOCl} ; \diamond, 75 \mu \mathrm{M} \mathrm{HOCl} ; \Delta, 50 \mu \mathrm{M}$ DTT $+50 \mu \mathrm{M}$ $\mathrm{HOCl} ; \Delta, 50 \mu \mathrm{M}$ glycine $+50 \mu \mathrm{M} \mathrm{HOCl} ; \nabla, 50 \mu \mathrm{M}$ methionine +50 $\mu \mathrm{M}$ HOCl.

$75 \mu \mathrm{M} \mathrm{HOCl}$ were found to lyse all cells. No cell lysis was observed with $<20 \mu \mathrm{M} \mathrm{HOCl}$ over a period of up to $6 \mathrm{~h}$.

Addition of $50 \mu \mathrm{M}$ DTT, glycine or methionine added before a bolus of $50 \mu \mathrm{M} \mathrm{HOCl}$ completely prevented HOClinduced cell lysis. Addition of the same scavenging species as little as $30 \mathrm{~s}$ after the exposure to $\mathrm{HOCl}$ had no protective effect.

For comparison, $200 \mu \mathrm{M} \mathrm{NH} \mathrm{NH}_{2} \mathrm{Cl}$ caused $5 \%$ and $300 \mu \mathrm{M}$ $32 \%$ cell lysis at $6 \mathrm{~h}, \sim 10 \%$ of the effect of HOCl. Up to 300 $\mu \mathrm{M}$ taurine chloramine (42) did not induce any lysis over a period of $6 \mathrm{~h}$.

LDH release was always less sensitive than trypan blue exclusion: a concentration of $\mathrm{HOCl}$ that caused trypan blue uptake in $60 \%$ of the cells, only led to a $25 \%$ loss of cellular LDH.

\section{Oxidation of protein moieties}

Sulfhydryl oxidation. To define biochemical targets of $\mathrm{HOCl}$ toxicity, various protein moieties of HOCl-treated cells were analyzed.

Protein sulfhydryls were particularly sensitive to oxidation by $\mathrm{HOCl}$. When total cellular sulfhydryls were determined, a decrease of -SH groups was observed with a threshold of 50-60 $\mu \mathrm{M} \mathrm{HOCl}$ (Fig. 2). The loss of -SH groups could be completely accounted for by disulfide formation up to $\mathrm{HOCl}$ concentrations of $120-150 \mu \mathrm{M}$. With higher concentrations of $\mathrm{HOCl}$ these disulfides, too, disappeared. Addition of $1 \mathrm{mM}$ methionine before the $\mathrm{HOCl}$ completely prevented $-\mathrm{SH}$ oxidation.

Glutathione became oxidized with the same concentrations of $\mathrm{HOCl}$ as total acid precipitable sulfhydryls (Fig. 2).

Due to the high reactivity of $\mathrm{HOCl}$ it was assumed that -SH groups of the plasma membrane were oxidized with lower concentrations of $\mathrm{HOCl}$. Extracellularly accessible $-\mathrm{SHs}$, measured by binding of I-PE, decreased with as little as $10 \mu \mathrm{M}$ $\mathrm{HOCl}$, and a maximal decrease was seen at 20-30 $\mu \mathrm{M} \mathrm{HOCl}$ (Fig. 2). $p$ CMBS decreased binding of I-PE in a similar concentration range as $\mathrm{HOCl}$.

The absolute amount of extracellularly accessible -SHs in control cells was determined as $25.0 \pm 4.9 \mathrm{pmol} / 10^{6}$ cells by $\left[{ }^{203} \mathrm{Hg}\right] p C M B S$ binding.

\section{Oxidation of methionine}

The dose response for methionine sulfoxide formation was identical to that for cysteine oxidation (Fig. 3). In control cells $8.1 \pm 0.35 \%$ of $\left[{ }^{35} \mathrm{~S}\right]$ methionine incorporated into protein was present as methionine sulfoxide. This percentage increased to

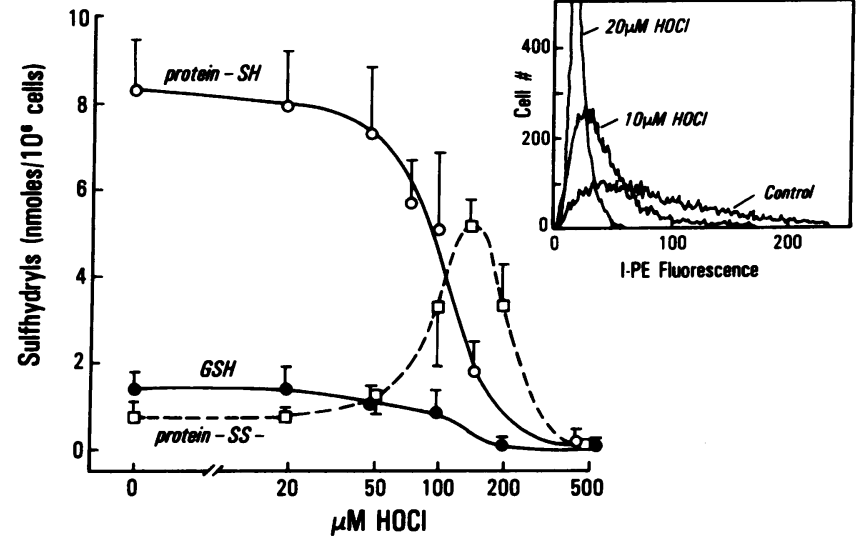

Figure 2. Sulfhydryl oxidation in P388D1 cells by HOCl. $2 \times 10^{6}$ P388Dl cells were exposed to doses of $\mathrm{HOCl}$ as shown on the abscissa for $15 \mathrm{~min}$ at $37^{\circ} \mathrm{C}$. The cells were then assayed $(a)$ for total protein sulfhydryls $O,(b)$ for total protein sulfhydryls and disulfides; the difference between the two assays represents disulfides $\square$, disulfide concentrations are represented as -SH equivalents, and $(c)$ for GSH •. (Inset) Determination of extracellularly accessible -SH groups: histogram of I-PE binding as described in Methods.

$13.0 \pm 0.53 \%$ after a 15 -min exposure to $20 \mu \mathrm{M} \mathrm{HOCl}$, and to $45.0 \pm 1.2 \%$ with $100 \mu \mathrm{M} \mathrm{HOCl}$.

Plasma membrane methionines were oxidized with smaller concentrations of $\mathrm{HOCl}$ than the bulk methionine content of the cell (Table I).

\section{Oxidation of tryptophans}

Tryptophans were also oxidized by $\mathrm{HOCl}$, although slightly higher concentrations were needed (Fig. 3). Assuming that 280 $\mathrm{nm}$ fluorescence of acid cell precipitates is tryptophan specific, control cells contained the equivalent of $2.27 \pm 0.21 \mathrm{nmol}$ tryptophans $/ 10^{6}$ cells, whereas cells exposed to $100 \mu \mathrm{M} \mathrm{HOCl}$ contained $1.74 \pm 0.45 \mathrm{nmol}$ tryptophan after $15 \mathrm{~min}$ exposure.

Formation of protein carbonyls. Formation of protein carbonyls was observed with similar concentrations (Fig. 3) of $\mathrm{HOCl}$, presumably due to deamination after chloramine formation of $\mathrm{NH}_{2}$-terminal amino acids and lysine residues (43).

Effect of $\mathrm{HOCl}$ on plasma membrane transporter function. Since $\mathrm{HOCl}$ is a potent $-\mathrm{SH}$ oxidizing reagent and since reduced thiols are essential for the function of various cellular transport systems (44-46), the effect of $\mathrm{HOCl}$ on some of these transporter activities was assessed.

Table I. Protein Methionine Sulfoxide Formation Induced by $\mathrm{HOCl}$ in Various Cellular Fractions

\begin{tabular}{ccccc}
\hline$\mu \mathrm{M}$ HOCI & p.m. & Cytoplasm & mito. & Nuclei \\
\hline 0 & $16.2 \pm 1.9$ & $14.0 \pm 2.6$ & $12.8 \pm 3.8$ & $13.3 \pm 3.7$ \\
35 & $27.7 \pm 8.3$ & $16.7 \pm 4.7$ & $21.6 \pm 8.0$ & $20.0 \pm 7.4$ \\
50 & $32.5 \pm 11.2$ & $21.5 \pm 7.8$ & $26.9 \pm 8.9$ & $22.6 \pm 6.3$
\end{tabular}

Plasma membranes (p.m.), cytoplasm, mitochondria and granules (mito.) and nuclei (+ some whole cells); $5 \times 10^{7}\left[{ }^{35}\right.$ S]methionine-labeled P388D 1 cells were exposed to $\mathrm{HOCl}$ for $15 \mathrm{~min}$, followed by cell fractionation and cyanogen bromide digestion as described in Methods. Results are expressed as percent $\left[{ }^{35}\right.$ S]methionine not cleaved by cyanogen bromide. Mean \pm SD for four experiments in duplicate. 


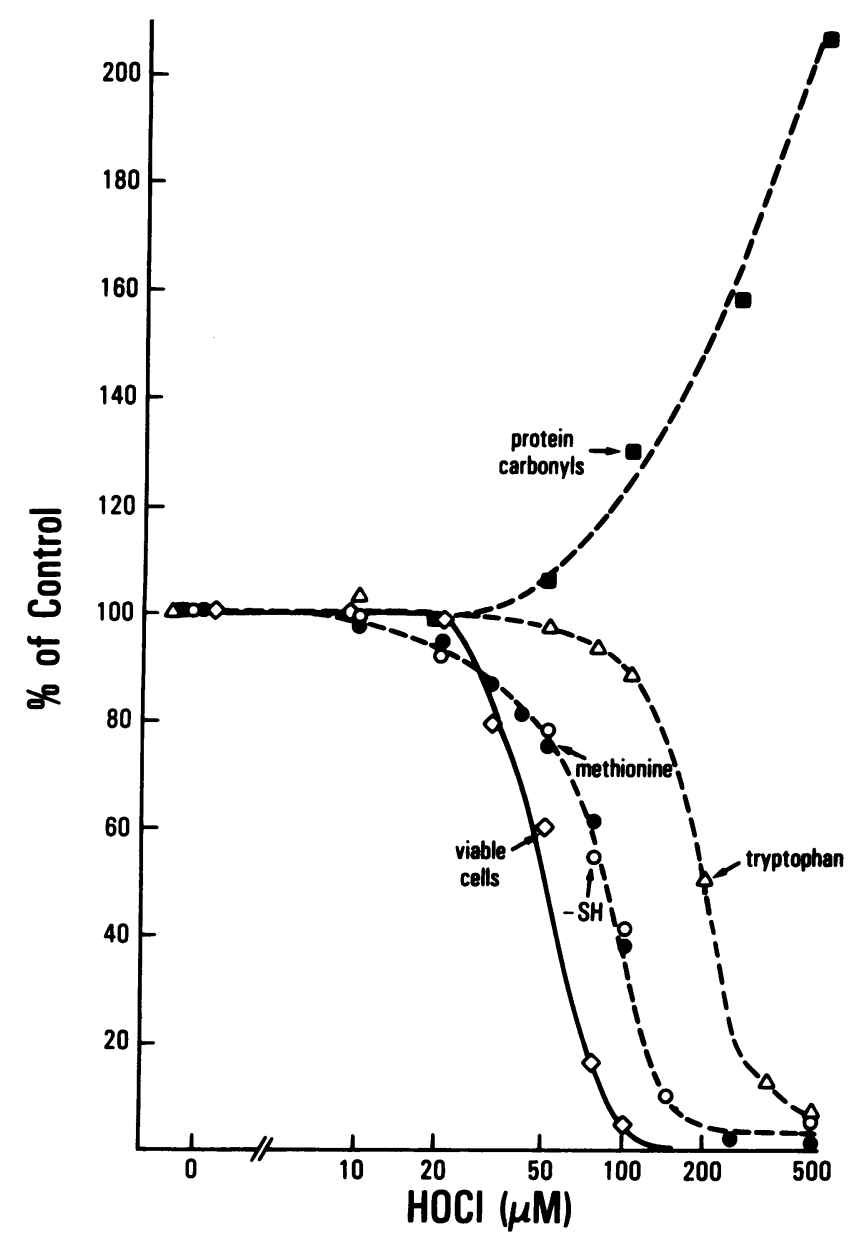

Figure 3. HOCl-induced oxidation of various cellular protein targets. Sulfhydryls were determined as described for Fig. 2. Methionine sulfoxides, tryptophans, and protein carbonyls were assayed as described in Methods. Mean of at least three experiments in duplicate, all determined after $15 \mathrm{~min}$ exposure to $\mathrm{HOCl}$. For comparison cell lysis data (trypan blue exclusion) at $\mathbf{3 0 ~} \mathrm{min}$ are shown in the same figure.

Effect of $\mathrm{HOCl}$ on glucose uptake. When $\left[{ }^{3} \mathrm{H}\right] 2$-deoxyglucose (DOG) uptake was determined in P388D1 cells exposed to $\mathrm{HOCl}$ for $15 \mathrm{~min}$, a dose-dependent inhibition of uptake was observed with complete inhibition at $50 \mu \mathrm{M} \mathrm{HOCl}$ (Fig. 4 $A)$. When a dose of cytochalasin B that half-maximally inhibits glucose uptake $(0.2 \mu \mathrm{M})(32,47)$ was added before the $\mathrm{HOCl}$, a parallel inhibition curve was obtained (Fig. $4 A$ ). This suggests that decreased $\left[{ }^{3} \mathrm{H}\right] 2-\mathrm{DOG}$ uptake at low concentrations of $\mathrm{HOCl}$ was due to transporter inactivation, although it is possible that inhibition of glucose uptake was a secondary effect, e.g., due to the loss of $\mathrm{Na}^{+}$and $\mathrm{K}^{+}$gradients across the plasma membrane (see below). With $>40 \mu \mathrm{M}$ HOCl leakage of 2-DOG-phosphate may have contributed to the low levels of intracellular $\left[{ }^{3} \mathrm{H}\right] \mathrm{DOG}$ measured since cells prelabeled with $\left[{ }^{3} \mathrm{H}\right] \mathrm{DOG}$ lost the label upon exposure to $>40 \mu \mathrm{M} \mathrm{HOCl}$ (data not shown).

pCMBS caused a similar inhibition of $\left[{ }^{3} \mathrm{H}\right] D O G$ uptake (Fig. $4 \mathrm{~A}$ ). Methionine prevented inhibition of glucose transport only if added before the $\mathrm{HOCl}$.

Effect of $\mathrm{HOCl}$ on $\left[{ }^{3} \mathrm{H}\right]$ aminoisobutyric acid uptake. Aminoisobutyric acid is taken up by the " $\mathrm{A}$ " transport system for amino acids, but is then not incorporated into protein. $\left[{ }^{3} \mathrm{H}\right]$ Aminoisobutyric acid uptake was inhibited by the same

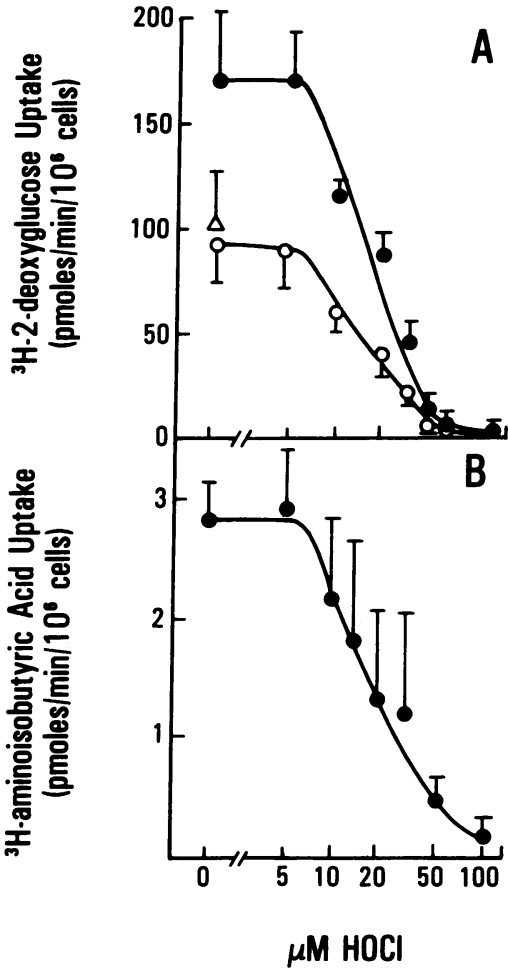

Figure 4. Inhibition of $\left[{ }^{3} \mathrm{H}\right] 2$-deoxyglucose and $\left[{ }^{3} \mathrm{H}\right]$ aminoisobutyric acid uptake by $\mathrm{HOCl}$. (A) Inhibition of $\left[{ }^{3} \mathrm{H}\right] 2$ deoxyglucose uptake by $\mathrm{HOCl}$, determined as described in the method section. $\bullet$, Cells treated with $\mathrm{HOCl}$ only, o, cells pretreated with $0.2 \mu \mathrm{M}$ cytochalasin B for 15 min before the addition of $\mathrm{HOCl}, \triangle$ cells incubated with $10 \mu \mathrm{M}$ pCMBS for $30 \mathrm{~min}$. (B) Inhibition of $\left[{ }^{3} \mathrm{H}\right]-$ aminoisobutyric acid uptake by $\mathrm{HOCl}$. Mean \pm SD of four experiments in duplicate.

concentrations of $\mathrm{HOCl}$ as the glucose transporter (Fig. $4 \mathrm{~B}$ ). $p C M B S$ again inhibited this transport system. When $5 \mu \mathrm{M}$ pCMBS and $10 \mu \mathrm{M} \mathrm{HOCl}$, either one of which caused about a $20 \%$ inhibition of transport on its own, were added together, this resulted in a $43 \%$ inhibition of aminoisobutyric acid uptake.

$\left[{ }^{3} \mathrm{H}\right]$ Leucine uptake which is transported by the " $\mathrm{L}$ "-system and is not $\mathrm{Na}^{+}$-dependent, was similarly inhibited by $\mathrm{HOCl}$, showing a $50 \%$ inhibition at $24 \mu \mathrm{M} \mathrm{HOCl}$.

Effect of $\mathrm{HOCl}$ on cell volume. The same concentration range of $\mathrm{HOCl}$ led to an increase of cell volume. The observation of cell swelling was originally made when examining cells exposed to $20-40 \mu \mathrm{M} \mathrm{HOCl}$ under the microscope. Fig. $5 A$ shows the increase of cell volume $30 \mathrm{~min}$ after the addition of a bolus of $\mathrm{HOCl}$ as measured on a FACS analyzer. ${ }^{3} \mathrm{H}_{2} \mathrm{O}$ space increased in parallel (Fig. $5 A$ ), but to a lesser degree. $p C M B S$, but not other sulfhydryl reagents ( $1 \mathrm{mM}$ iodoacetate, $200 \mu \mathrm{M}$ $n$-ethylmaleimide, or $1 \mathrm{mM}$ DTNB) caused a similar increase in cell volume (Fig. $5 \mathrm{~A}$ ). When cells were exposed to $\mathrm{HOCl}$ in the presence of $p C M B S$, an additive effect on cell volume was observed (Fig. $5 \mathrm{~B}$ ).

The increase in volume of P388D1 cells could be largely prevented, when $1 \mathrm{mM}$ DTT was added $30 \mathrm{~s}$ after the addition of $\mathrm{HOCl}$, suggesting a sulfhydryl oxidation mediated mechanism (Fig. $5 B$ ).

When the $\mathrm{Na}^{+}$buffer was replaced by choline chloride, a much bulkier molecule, the increase in cell volume was similarly prevented (Fig. 5 B). The same replacement of MGB by choline chloride did not prevent cell lysis nor did it prevent the efflux of ${ }^{86} \mathrm{Rb}$ from cells exposed to $\mathrm{HOCl}$ (see below). Thus the increase in cell volume was associated with, but not causative of $\mathrm{HOCl}$ induced cell lysis.

Effect of HOCl on cation fluxes. Since the volume increase and its inhibition by choline chloride suggested that $\mathrm{HOCl}$ caused an ionic imbalance, cellular cations were determined. 

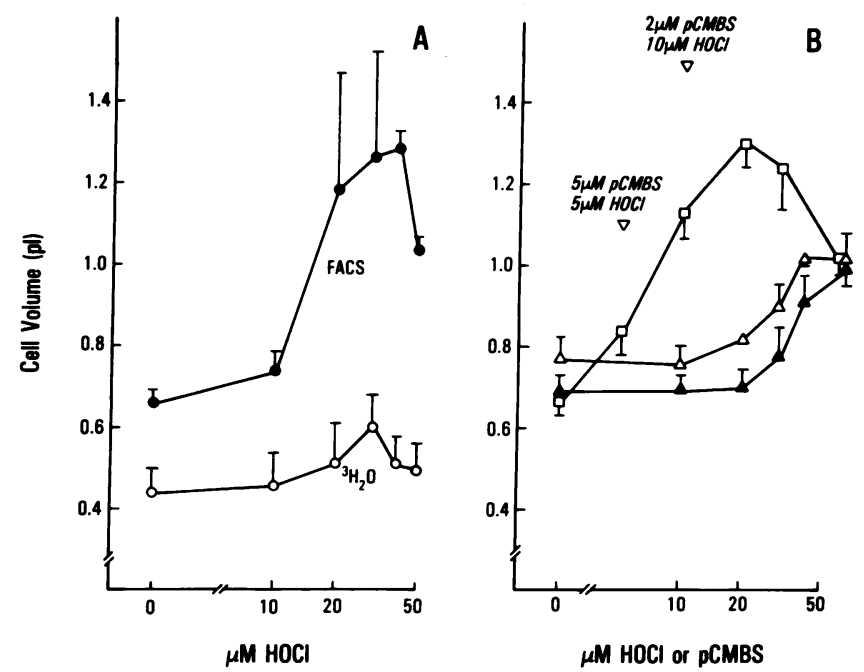

Figure 5. Effect of $\mathrm{HOCl}$ on cell volume. Cell volume was measured on a FACS analyzer or by uptake of ${ }^{3} \mathrm{H}_{2} \mathrm{O}$ as described in Methods. 2 $\times 10^{6}$ cells were incubated with $\mathrm{HOCl}$ for $30 \mathrm{~min}$ at $37^{\circ} \mathrm{C}$. $(A) \bullet$, FACS volume of P388Dl cells exposed to $\mathrm{HOCl}$ for $30 \mathrm{~min} ; \mathrm{O}^{3}{ }^{3} \mathrm{H}_{2} \mathrm{O}$ space of $\mathrm{P} 388 \mathrm{Dl}$ cells exposed to $\mathrm{HOCl}$ for $30 \mathrm{~min}$. (B) Modulation of cell volume by various means as analyzed by FACS: $\triangle$, effect of 1 mM DTT $30 \mathrm{~s}$ after the addition of $\mathrm{HOCl} ; \Delta$, effect of replacement of $\mathrm{NaCl}$ by choline chloride before the addition of $\mathrm{HOCl} ; \square$, effect of the sulfhydryl reagent $p C M B S$ on cell volume in the absence of $\mathrm{HOCl}$, molarities are the same as for $\mathrm{HOCl}, \nabla$, effect of combined $\mathrm{HOCl} / p \mathrm{CMBS}$ incubation. Mean $\pm \mathrm{SD}$ of at least three experiments for FACS analysis; $n=18$ for ${ }^{3} \mathrm{H}_{2} \mathrm{O}$ space.

When intracellular cations $\left(\mathrm{K}^{+}, \mathrm{Ca}^{2+}, \mathrm{Na}^{+}\right)$were measured by atomic absorption, a fast decrease of $\mathrm{K}^{+}$was observed (Fig. 6). $\mathrm{Ca}^{2+}$ and $\mathrm{Na}^{+}$concentrations increased over time, but with poor reproducibility (data not shown). Presumably cations leaked out of the cells again during the period of time necessary for the choline chloride washes. To circumvent this problem cells were labeled with the fluorescent $\mathrm{Na}^{+}$-probe SBFIAM. Intracellular $\mathrm{Na}^{+}$determined by this method increased from $<10 \mathrm{mM}$ to apparently $20 \mathrm{mM}$ with $10 \mu \mathrm{M} \mathrm{HOCl}$ at $30 \mathrm{~min}$.

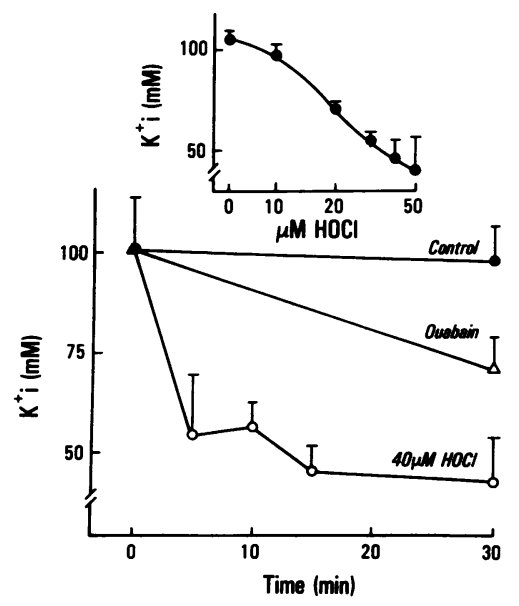

Figure 6. Effect of $\mathrm{HOCl}$ on cellular $\mathrm{K}^{+}$ concentrations. The potassium content of 3 $\times 10^{7} \mathrm{P} 388 \mathrm{D} 1$ cells was determined by atomic absorption as previously described (33). Cells were exposed to $40 \mu \mathrm{M}$ $\mathrm{HOCl}$ for 5 to $30 \mathrm{~min}$ at $37^{\circ} \mathrm{C}$. For comparison $\mathrm{K}^{+}$-concentrations were also determined in cells incubated with 0.2 $\mathrm{mM}$ ouabain to inhibit $\mathrm{Na}^{+}-\mathrm{K}^{+}$-ATPase. $\mathrm{K}^{+}$ molarities were calculated assuming a cell volume of $0.7 \mathrm{pl}$, obtained from the FACS analysis. The insert shows a dose response to $\mathrm{HOCl}$ induced $\mathrm{K}^{+}$-loss determined after a 30 -min incubation at $37^{\circ} \mathrm{C}$.
Compatible results were observed using ${ }^{86} \mathrm{Rb}$ as an indicator of $\mathrm{K}^{+}$fluxes. $10 \mu \mathrm{M} \mathrm{HOCl}$ was sufficient to induce an instant increase in the rate of ${ }^{86} \mathrm{Rb}$ efflux from P388D1 cells (Fig. $7 \mathrm{~A}$ ). ${ }^{86} \mathrm{Rb}$-efflux stayed increased in $\mathrm{HOCl}$-injured cells incubated at $4^{\circ} \mathrm{C}$, suggestive of involvement of a passive leak. A similar increase in ${ }^{86} \mathrm{Rb}$ efflux was observed with the cell-impermeable sulfhydryl oxidant $p$ CMBS $(10 \mu \mathrm{M})$, while $1 \mathrm{mM}$ iodoacetic acid (data not shown) had no effect. Addition of 5 $\mu \mathrm{M} p \mathrm{CMBS}$, which did not cause an increased ${ }^{86} \mathrm{Rb}$ efflux by itself, and $10 \mu \mathrm{M} \mathrm{HOCl}$ caused a measurable enhancement of ${ }^{86} \mathrm{Rb}$ efflux when added together (Fig. $7 \mathrm{~A}$ ).

$5 \mathrm{mM} \mathrm{BaCl}_{2}$, an inhibitor of $\mathrm{K}^{+}$channels (48), prevented $\mathrm{HOCl}$ induced increased ${ }^{86} \mathrm{Rb}$ efflux at low concentrations of $\mathrm{HOCl}(5-20 \mu \mathrm{M})$, but only slightly inhibited the ${ }^{86} \mathrm{Rb}$ efflux at higher concentrations (Fig. $7 \mathrm{~B}$ ).

Since plasma membrane ATPases are important for the regulation of cellular ion homeostasis, P388D1 cells were exposed to $\mathrm{HOCl}$ for $15 \mathrm{~min}$ and plasma membranes were then isolated. Inhibition of both $\mathrm{Na}^{+}-\mathrm{K}^{+}$-ATPase and $\mathrm{Ca}^{2+}$-ATPase activity were observed (Table II). However, the concentrations of $\mathrm{HOCl}(30-40 \mu \mathrm{M})$ required to inhibit the ATPases, were higher than those sufficient to cause marked ionic disturbances in the cells. The greater loss of $\mathrm{K}^{+}$in $\mathrm{HOCl}$ injured cells as compared to ouabain-treated cells (Fig. 6) also indicates that ATPase inactivation is not sufficient to explain the observed ionic disturbance. No effect of $\mathrm{HOCl}$ on membrane potential could be observed with either 3,3'dipentyloxacarbocyanine $\left(\mathrm{Di}-\mathrm{O}-\mathrm{C}_{5}\right)$ and FACS analysis $(49)$ or $\left[{ }^{3} \mathrm{H}\right]$ tetraphenylphosphonium bromide distribution (50). With the latter method a membrane potential of $\psi=-71 \pm 9 \mathrm{mV}$ was calculated for control cells, while cells exposed to $30 \mu \mathrm{M} \mathrm{HOCl}$ showed a $\psi$ $=-73 \pm 7 \mathrm{mV}$. The ionic redistribution in the presence of $\mathrm{HOCl}$ thus did not appear electrogenic in these cells.

Effect of $\mathrm{HOCl}$ on lipid peroxidation. Up to $200 \mu \mathrm{M} \mathrm{HOCl}$ added to whole cells did not cause lipid peroxidation as determined by the malonaldehyde assay ( 51 ), but could induce lipid peroxidation in liposomes (unpublished observation).

Effect of $\mathrm{HOCl}$ on intracellular targets. The data presented thus far indicate that $\mathrm{HOCl}$ in low concentrations $(10-20 \mu \mathrm{M})$ rapidly induces oxidative changes in proteins of the plasma

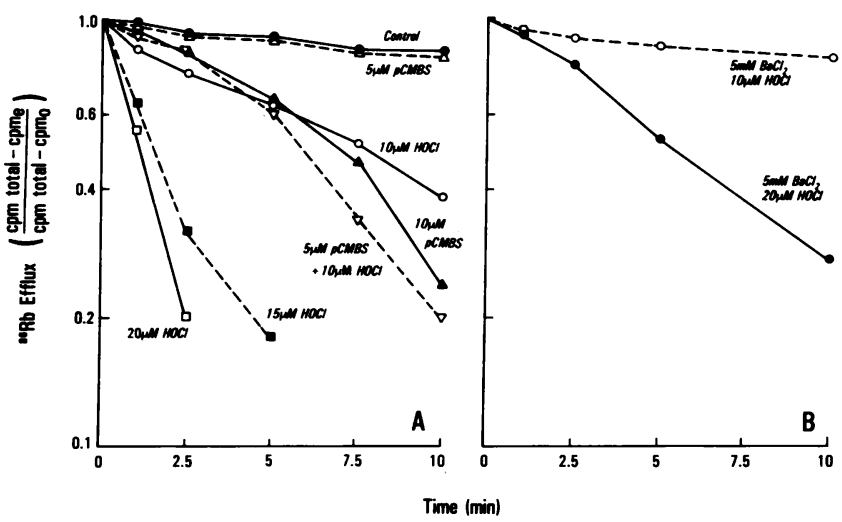

Figure 7. $(A \text { and } B)^{86} \mathrm{Rb}-e f f l u x$ in $\mathrm{P} 388 \mathrm{D} 1$ cells exposed to $\mathrm{HOCl}$ : ${ }^{86} \mathrm{Rb}$-efflux was determined as described in Methods. The fraction of ${ }^{86} \mathrm{Rb}$ retained by the cells was calculated from $\mathrm{cpm}_{\max }-\mathrm{cpm}_{\mathrm{e}} / \mathrm{cpm}_{\max }-$ $\mathrm{cpm}_{0}$, where $\mathrm{cpm}_{\max }$ represents the maximal cpm released by the cells ( $\sim 98 \%$ of total cpm), $\mathrm{cpm}_{\mathrm{e}}$ the counts of the experimental sample, and $\mathrm{cpm}_{0}$ the cpm released at 0 time. For comparison cells were treated in parallel with $10 \mu \mathrm{M} p \mathrm{CMBS}$. 
Table II. Inactivation of Plasma Membrane ATPase by $\mathrm{HOCl}$

\begin{tabular}{cccc}
\hline$\mu \mathrm{M} \mathrm{HOCl}$ & Total ATPase & $\mathrm{Na}^{+} / \mathrm{K}^{+} \mathrm{ATPase}$ & $\mathrm{Ca}^{2+} \mathrm{ATPase}$ \\
\hline \multicolumn{4}{c}{$\mu m o l$ PO4/h per mg protein } \\
$0(n=5)$ & $1,673 \pm 213$ & $218 \pm 09$ & $540 \pm 12$ \\
$20(n=2)$ & 1,573 & 200 & 533 \\
$40(n=5)$ & $1,210 \pm 169$ & $68 \pm 55$ & $347 \pm 143$ \\
$60(n=5)$ & $629 \pm 272$ & $70 \pm 37$ & $196 \pm 111$
\end{tabular}

$1 \times 10^{8} \mathrm{P} 388 \mathrm{D} 1$ cells $/ 50 \mathrm{ml}$ were exposed to $\mathrm{HOCl}$ for $15 \mathrm{~min}$. Plasma membranes were prepared by differential centrifugation and ATPase activity was determined as described in Methods. $\mathrm{Na}^{+} / \mathrm{K}^{+}$ATPase and $\mathrm{Ca}^{2+}$ ATPase activities were calculated from the total activity minus the activity in the presence of $0.2 \mathrm{mM}$ ouabain or $5 \mathrm{mM}$ EGTA, respectively.

membrane. We then examined the possibility that $\mathrm{HOCl}$ could traverse the plasma membrane to induce oxidative changes intracellularly. Several intracellular targets were examined: GAPDH, hexokinase, DNA, NAD, and ATP, and mitochondrial $\mathrm{O}_{2}$ consumption.

GAPDH of the glycolytic pathway is very sensitive to oxidative inactivation $(16,32)$ and was indeed inhibited with concentrations of $\mathrm{HOCl}$ that did not cause cell lysis (Fig. $8 \mathrm{~A}$ ). If cells were lysed with $0.01 \%$ digitonin before the addition of $\mathrm{HOCl}, 90 \%$ inactivation of GAPDH was seen with $10 \mu \mathrm{M}$ $\mathrm{HOCl}$, indicating that the cytoplasmic location protects GAPDH from inactivation in intact cells to a considerable degree, but not completely. pCMBS similarly inactivated GAPDH (59\% inactivation at $10 \mu \mathrm{M})$ in spite of its poor membrane permeability (44).

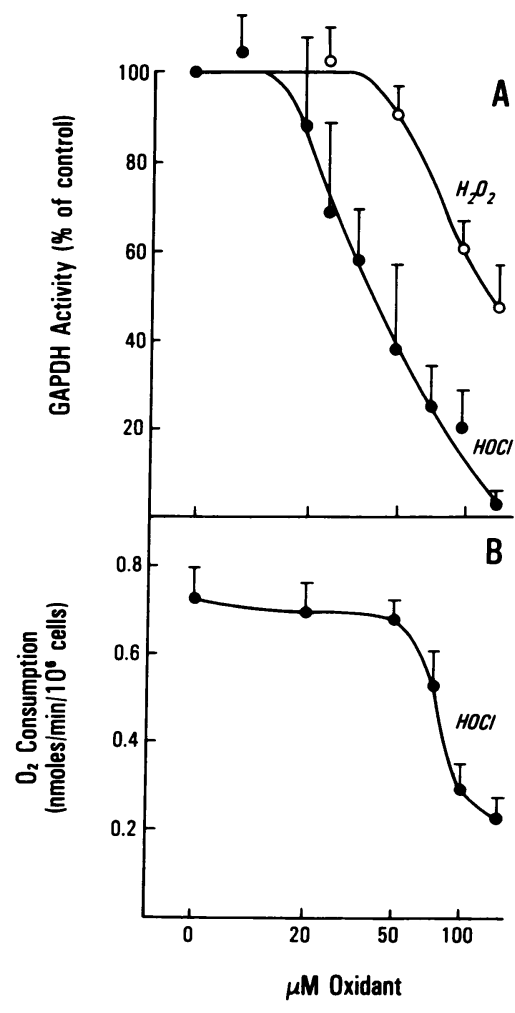

Figure 8. Effect of $\mathrm{HOCl}$ on GAPDH activity and mitochondrial respiration: $\mathrm{O}_{2}$ consumption as well as GAPDH activity were determined after a 15 min exposure to $\mathrm{H}_{2} \mathrm{O}_{2}$.
$\mathrm{HOCl}$ was able to inactivate other enzymes of the glycolytic pathway such as hexokinase. The concentrations needed (120 $\mu \mathrm{M}$ for $50 \%$ inhibition) were, however, higher than those inducing cell death.

Lactate formation from $\mathrm{U}\left[{ }^{14} \mathrm{C}\right]$ glucose was similarly decreased by $\mathrm{HOCl}$ (Table III), but may have been due to inhibition of glucose uptake rather than GAPDH inactivation.

Mitochondrial respiration was also inhibited by $\mathrm{HOCl}$, but again fairly high concentrations of the oxidant were necessary: half-maximal inhibition of basal $\mathrm{O}_{2}$ consumption in whole P388D 1 cells was observed with $80 \mu \mathrm{M} \mathrm{HOCl}$ (Fig. $8 \mathrm{~B}$ ).

Cellular ATP concentrations fell after the addition of $\mathrm{HOCl}$ (Fig. $9 \mathrm{~A}$ ). No extracellular ATP was observed under these conditions. This loss of ATP with low concentrations of $\mathrm{HOCl}$ thus was presumably due to changes in ATP metabolism, such as glucose transport inhibition. With more severe injury it became impossible to differentiate between inhibition of ATP synthesis and leakage of ATP into the extracellular medium, followed by extracellular degradation: When cells lost $89 \%$ of their ATP, $60 \%$ of the remaining ATP was found in the extracellular medium, indicating that it was not degraded, but lost due to permeability changes in the plasma membrane.

In contrast to $\mathrm{H}_{2} \mathrm{O}_{2}, \mathrm{HOCl}$ in concentrations up to $200 \mu \mathrm{M}$ did not induce DNA strand breaks in P388D1 cells or isolated PM2 phage DNA. Nor could the sequelae of DNA strand break formation seen in $\mathrm{H}_{2} \mathrm{O}_{2}$ injured cells (8) including activation of poly-ADP-ribose-polymerase and early NAD depletion be observed. Fig. $9 \mathrm{~B}$ shows the effect of $\mathrm{HOCl}$ on cellular NAD levels. Lost intracellular NAD could be quantitatively recovered in the extracellular fluid, indicating that it was not degraded, but lost due to permeability changes in the plasma membrane.

\section{Discussion}

Injurious effects of $\mathrm{HOCl}$ on cells at low concentrations of $\mathrm{HOCl}$. These results suggest that $\mathrm{HOCl}$ in concentrations as low as $10-20 \mu \mathrm{M}$ rapidly oxidizes proteins but not lipids-in the external membrane of cells as shown by binding of I-PE. The damage to membrane proteins leads to loss of homeostatic control of ions especially $\mathrm{K}^{+}$across the plasma membrane and causes cell swelling. Table IV summarizes and compares the effect of $\mathrm{HOCl}$ on various cellular targets: plasma membrane protein functions (I-PE accessible -SH groups, $\mathrm{K}^{+}$efflux, DOG and aminoisobutyric acid uptake, cell volume) are half-maximally affected by $\sim 20 \mu \mathrm{M} \mathrm{HOCl}$. The

Table III. Lactate Formation from $\left.U^{14} \mathrm{C}\right]$ Glucose in P388DI Cells Exposed to $\mathrm{HOCl}$ for $30 \mathrm{~min}$ in $M G B$ Containing $100 \mu M$ Glucose

\begin{tabular}{cc}
\hline$\mu \mathrm{M} \mathrm{HOCl}$ & Lactate formation \\
\hline 0 & pmol/10 $0^{6}$ cells per min \\
10 & $153 \pm 43$ \\
20 & $140 \pm 35$ \\
30 & $99 \pm 46$ \\
40 & $67 \pm 53$ \\
50 & $55 \pm 49$ \\
\end{tabular}

Lactate was determined as described in Methods. Mean \pm SD of four experiments. 

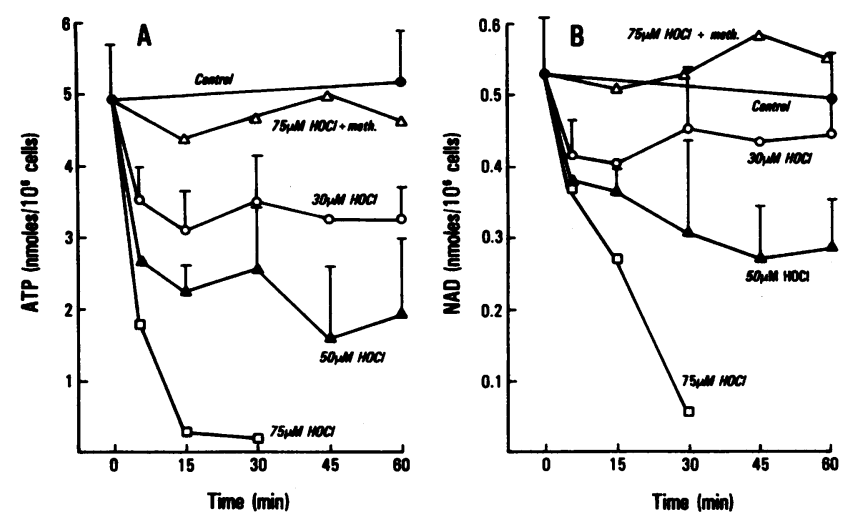

Figure 9. Effect of $\mathrm{HOCl}$ on cellular ATP and NAD concentrations determined by HPLC (36): mean and SD of three experiments. Meth, methionine.

same changes were observed in the presence of $p C M B S$, which acts primarily with plasma membrane -SHs $(44,45,52)$. The additive effect of $\mathrm{HOCl}$ and $p \mathrm{CMBS}$ on ${ }^{86} \mathrm{Rb}$ efflux, aminoisobutyric acid uptake and increase in cell volume suggests that the two reagents act upon functionally similar cellular targets, presumably extracellularly accessible -SH groups.

Under conditions where glucose uptake is inhibited by $\sim 75 \%$, ATP formation and lactate production are inhibited by $\sim 50 \%$. GAPDH is inactivated in the same concentration range. It is not clear at this point whether the inactivation of GAPDH was caused by penetration of a small amount of $\mathrm{HOCl}$ into the cell, or whether GAPDH is inactivated due to -SS- exchange between extra- and intracellular moieties; on the one hand $\mathrm{HOCl}$ can penetrate lipid vesicles and bleach 5-carboxyfluorescein inside these vesicles leading to decreased fluorescence after Triton X-100 lysis of these liposomes (53) ex-

Table IV. Comparison of Effect of $\mathrm{HOCl}$ on Various Cellular Parameters

\begin{tabular}{lc}
\hline \multicolumn{1}{c}{ Parameter determined } & $\begin{array}{c}\text { Concentration of } \mathrm{HOCl} \text { inducing } \\
\text { half-maximal effect }\end{array}$ \\
\hline Loss of I-PE binding & $\mu M$ \\
$\mathrm{~K}_{\mathrm{i}}^{+}$loss & 12 \\
Inhibition of [ $\left.{ }^{3} \mathrm{H}\right] \mathrm{DOG}$ uptake & 18 \\
Inhibition of [ $\left.{ }^{3} \mathrm{H}\right] \mathrm{AIBA}$ uptake & 20 \\
FACS vol. increase & 20 \\
ATP loss & 21 \\
Inhibition of lactate formation & 29 \\
GAPDH inactivation & 30 \\
NAD loss & 36 \\
Trypan blue uptake & 50 \\
LDH loss & 50 \\
Inhibition of $\mathrm{O}_{2}$ consumption & 79 \\
\end{tabular}

All parameters were determined after a 30-min exposure of $2 \times 10^{6}$ $\mathrm{P} 388 \mathrm{D} 1 \mathrm{cells} / \mathrm{ml}$ at $37^{\circ} \mathrm{C}$. Concentrations of $\mathrm{HOCl}$ inducing a halfmaximal effect were extrapolated from dose-response curves. For $\mathrm{K}_{i}^{+}$ loss the amount of $\mathrm{K}_{\mathrm{i}}^{+}$retained in cells lysed with $0.01 \%$ digitonin $(40 \mathrm{mM})$ was subtracted, since it presumably represented $\mathrm{K}^{+}$contained in organelles. $\mathrm{LDH}_{\mathrm{i}}$ stands for intracellular $\mathrm{LDH},\left[{ }^{3} \mathrm{H}\right] \mathrm{AIBA}$ for $\left[{ }^{3} \mathrm{H}\right]$ aminoisobutyric acid. ATP, NAD, trypan blue exclusion, and LDH data were obtained in parallel on the same samples to allow direct comparison. posed to $\mathrm{HOCl}$ (data not shown). On the other hand it has been suggested that there is a shuttling mechanism between extracellular and cytoplasmic -SS- groups (54) such that the inactivation of GAPDH could be secondary to plasma membrane oxidation. This mechanism would also explain that pCMBS, acting only at the surface, inactivated GAPDH.

Injurious effects of $\mathrm{HOCl}$ at high concentrations of $\mathrm{HOCl}$. Slightly higher concentrations of $\mathrm{HOCl}(50 \mu \mathrm{M})$ led to cell lysis assessed by trypan blue exclusion as well as to leakage of NAD into the extracellular medium. In $\mathrm{HOCl}$-mediated injury loss of trypan blue exclusion was a more sensitive measure of cell lysis than LDH release (Table IV), suggesting that $\mathrm{HOCl}$ induced cell death was due to perturbation of plasma membrane integrity with preferential leakage of small molecules.

The nonspecific protein oxidation caused by $\mathrm{HOCl}$ made it difficult to disect malfunctioning of specific pathways as causative of cell death. Various SH-oxidizing agents (e.g., pCMBS, cystamine) (55) cause cell death, and it is likely that $\mathrm{HOCl}$ induces cell death due to sulfhydryl oxidation. However, sublytic concentrations of $\mathrm{HOCl}$ may be sufficient to cause cellular dysfunction (56).

Comparison between cellular targets of $\mathrm{HOCl}$ and $\mathrm{H}_{2} \mathrm{O}_{2}$. $\mathrm{H}_{2} \mathrm{O}_{2}$ is capable of oxidizing -SHs but did not cause general protein -SH oxidation in P388D1 cells when as much as $5 \mathrm{mM}$ $\mathrm{H}_{2} \mathrm{O}_{2}$ was added. This was presumably due to the very active glutathione cycle and HMPS present in these cells, which keep intracellular sulfhydryls reduced (29). Conditions of peroxide induced protein -SH oxidation in hepatocytes were always preceded by complete GSH depletion (57), while protein -SHs and GSH disappeared concomitantly in the presence of $\mathrm{HOCl}$. $\mathrm{H}_{2} \mathrm{O}_{2}$ induced -SH oxidation was very specific. When analyzing the effect of $5 \mathrm{mM} \mathrm{H}_{2} \mathrm{O}_{2}$ on the $K_{\mathrm{m}}$ and $V_{\max }$ of every enzyme of the glycolytic pathway, only GAPDH was affected. No such specificity was seen with $\mathrm{HOCl}(16)$, which rather indiscriminately oxidized -SHs.

Similarly, when sulfhydryl-dependent plasma membrane functions were determined only $\mathrm{HOCl}$, but not $\mathrm{H}_{2} \mathrm{O}_{2}$ affected these parameters in our system: glucose transport, amino acid transport, and plasma membrane ATPases were all inhibited by $\mathrm{HOCl}$, but not by $\mathrm{H}_{2} \mathrm{O}_{2}(8,32) . \mathrm{H}_{2} \mathrm{O}_{2}$ had no effect on cell volume (34) and $\mathrm{K}^{+}$loss was a late event that presumably followed $\mathrm{Na}^{+} \mathrm{K}^{+}$-ATPase inactivation due to $>90 \%$ depletion of cellular ATP $(33,58)$. While $\mathrm{HOCl}$ preferably oxidized targets of the plasma membrane, $\mathrm{H}_{2} \mathrm{O}_{2}$ diffuses into cells similar to $\mathrm{H}_{2} \mathrm{O}$. It reacts directly with very few targets, e.g., GAPDH, but forms ${ }^{\circ} \mathrm{OH}$ when reacting with transition metal. $\mathrm{H}_{2} \mathrm{O}_{2}$ induced damage to DNA, lipids (59) or ATPases (60) is dependent on the presence of free transition metals.

Table $\mathrm{V}$ summarizes the effect of $\mathrm{HOCl}$ and $\mathrm{H}_{2} \mathrm{O}_{2}$ on various cellular targets.

$\mathrm{H}_{2} \mathrm{O}_{2}$-induced cell death appears to be a late event following $>90 \%$ depletion of ATP $(8,59)$, disturbance of cellular $\mathrm{Ca}^{2+}$ homeostasis $(33,57)$, and cytoskeletal derangement (55). DNA damage although induced by very small concentrations of $\mathrm{H}_{2} \mathrm{O}_{2}$ is not necessarily followed by loss of cell integrity. $\mathrm{HOCl}$-induced cell death, on the other hand, occurs rapidly. Looking at cell membrane integrity, it is $\sim 10$ times more cytotoxic than $\mathrm{H}_{2} \mathrm{O}_{2}$, and since at least $30-40 \%$ of the $\mathrm{H}_{2} \mathrm{O}_{2}$ produced by stimulated PMNs is converted into $\mathrm{HOCl}(13$, 14), local $\mathrm{HOCl}$ formation may well be in the $100-\mu \mathrm{M}$ range. $\mathrm{HOCl}$ did not induce DNA strand breaks and while it is likely that $\mathrm{HOCl}$ will react with DNA bases (16), it is doubtful that it can reach nuclear sites except after cell lysis. 
Table V. Comparison of Targets of $\mathrm{H}_{2} \mathrm{O}_{2}$ and $\mathrm{HOCl}$

\begin{tabular}{|c|c|}
\hline $\mathrm{H}_{2} \mathrm{O}_{2}$ & $\mathrm{HOCl}$ \\
\hline \multicolumn{2}{|l|}{ Degradation } \\
\hline $\begin{array}{l}\text { Degraded enzymatically, } \\
\text { (catalase, GSH cycle) }\end{array}$ & $\begin{array}{l}\text { Degraded by reaction with } \\
\text { amino acids, proteins, etc. }\end{array}$ \\
\hline \multicolumn{2}{|l|}{ Location of targets } \\
\hline $\begin{array}{l}\text { Diffuses freely into cells, site- } \\
\text { directed damage due to } \\
\text { metal-dependent }{ }^{\circ} \mathrm{OH} \\
\text { formation }\end{array}$ & Reacts with closest target \\
\hline \multicolumn{2}{|l|}{ Cell death } \\
\hline $\begin{array}{l}\text { Lysis after several hours; } \\
\text { threshold dose } 250-300 \mu \mathrm{M}\end{array}$ & $\begin{array}{l}\text { Lysis within } 1 \mathrm{~h} \text {; } \\
\text { threshold dose } 25-35 \mu \mathrm{M}\end{array}$ \\
\hline \multicolumn{2}{|l|}{ Sulfhydryl oxidation } \\
\hline $\begin{array}{l}\text { Total -SH: no general } \\
\text {-SH oxidation at } \\
\text { millimolar concentrations, } \\
\text { very specific targets (e.g., } \\
\text { GAPDH) }\end{array}$ & $\begin{array}{l}50 \% \text { oxidation at } 100 \mu \mathrm{M} \text {, } \\
\text { Multiple molecular targets }\end{array}$ \\
\hline $\begin{array}{l}\text { Extracellular -SH: } 25 \% \\
\text { oxidized at } 700 \mu \mathrm{M} \mathrm{H}_{2} \mathrm{O}_{2} \text {, } \\
\text { no functional consequences }\end{array}$ & $\begin{array}{l}50 \% \text { oxidation at } 12 \mu \mathrm{M} \\
\text { dysfunction of }-\mathrm{SH} \text { dependent } \\
\text { plasma membrane proteins }\end{array}$ \\
\hline \multicolumn{2}{|l|}{ Cause of ATP depletion } \\
\hline Inactivation of GAPDH & Inactivation of GAPDH \\
\hline $\begin{array}{l}\text { Inhibition of mitochondrial } \\
\text { ADP-phosphorylation } \\
\text { preceding cell death by } \\
\text { hours }\end{array}$ & $\begin{array}{l}\text { Inhibition of mitochondrial } \\
\text { ADP-phosphorylation } \\
\text { Inhibition of glucose transport } \\
\text { barely preceding cell death }\end{array}$ \\
\hline \multicolumn{2}{|l|}{$D N A$} \\
\hline $\begin{array}{l}\text { DNA strand breaks at }<100 \\
\mu \mathrm{M}, \text { base hydroxylations, } \\
\text { activation of poly-ADPRP } \\
\text { causing severe NAD } \\
\text { depletion }\end{array}$ & $\begin{array}{l}\text { No DNA strand breaks at } 200 \\
\mu \mathrm{M} \text {, base oxidation products } \\
\text { unknown } \\
\text { NAD loss at time of cell lysis }\end{array}$ \\
\hline
\end{tabular}

Molarities refer to results obtained in P388D1 cells.

Comparison between $\mathrm{HOCl}$ and chloramines. Chloramine toxicity has been investigated in much more detail at this point (21-23), and there are problems in differentiating the effects of one from the other. While amino acids as well as $\mathrm{NH}_{4}^{+}$are abundant in vivo, direct effects of $\mathrm{HOCl}$ cannot be excluded since MPO binds avidly to target cells thus directing $\mathrm{HOCl}$ formation to the plasma membrane. Since our buffer was protein and amino acid-free and the release of $\mathrm{NH}_{4}^{+}$from $2 \times 10^{6}$ P388D1 cells did not exceed 14.0 $\pm 3.2 \mathrm{nmol}$ over a period of $30 \mathrm{~min}$ at $37^{\circ} \mathrm{C}$, chloramines were no primary source of oxidants in our system, although secondary chloramine formation from cellular proteins cannot be excluded. Indeed, in vivo the formation of less reactive chloramines may serve a protective role.

In summary, $\mathrm{HOCl}$ proved to be cytotoxic to $\mathrm{P} 388 \mathrm{D} 1$ cells with a threshold dose of 20-30 $\mu \mathrm{M}$. Even lower doses of $\mathrm{HOCl}$ inhibited various sulfhydryl dependent plasma membrane functions.

\section{Acknowledgments}

We wish to thank Donald McQuitty for operating the FACS, and Monica Bartlett for secretarial assistance.
This is publication 5856-IMM of the Department of Immunology. This work was supported by National Institutes of Health grant HL-23584, Office of Naval Research Contract 105-837, and a fellowship from the Parker B. Francis Foundation to Dr. Jackson.

\section{References}

1. Cochrane, C. G., R. G. Spragg, and S. D. Revak. 1983. Studies on the pathogenesis of the adult respiratory distress syndrome. Evidence of oxidant activity in bronchoalveolar lavage fluid. J. Clin. Invest. 71:754-761.

2. Till, G. O., K. J. Johnson, R. Kunkel, and P. A. Ward. 1982. Intra-vascular activation of complement and acute lung injury. Dependency on neutrophils and toxic oxygen metabolites. J. Clin. Invest. 71:1126-1135.

3. Schraufstätter, I. U., S. D. Revak, and C. G. Cochrane. 1984. Proteases and oxidants in experimental pulmonary inflammatory injury. J. Clin. Invest. 72:789-801.

4. Lee, C. T., A. M. Fein, M. Lippmann, H. Holtzman, P. Kimbel, and G. Weinbaum. 1981. Elastolytic activity in pulmonary lavage fluid from patients with adult respiratory distress syndrome. $N$. Engl. J. Med. 304:192-196.

5. Nathan, C. F., S. C. Silverstein, L. H. Brukner, and Z. A. Cohn. 1979. Extracellular cytolysis by activated macrophages and granulocytes II. Hydrogen peroxide as a mediator of cytotoxicity. J. Exp. Med. 149:100-113.

6. Weiss, S. J., J. Young, A. F. LoBuglio, and A. Slivka. 1981. Role of hydrogen peroxide in neutrophil-mediated destruction of cultured endothelial cells. J. Clin. Invest. 68:714-724.

7. Simon, R. H., C. H. Scoggin, and D. Patterson. 1981. Hydrogen peroxide causes the total injury to human fibroblasts exposed to oxygen radicals. J. Biol. Chem. 256:7181-7186.

8. Schraufstätter, I. U., D. B. Hinshaw, P. A. Hyslop, R. G. Spragg, and C. G. Cochrane. 1986. Oxidant injury of cells: DNA strand breaks activate poly-ADP-ribose polymerase and lead to depletion of NAD. $J$. Clin. Invest. 77:1312-1320.

9. Pontremoli, S., E. Melloni, M. Michetti, O. Sacco, B. Sparatore, F. Salamino, G. Damiani, and B. L. Horecker. 1986. Cytolytic effects of neutrophils. Role for a membrane-bound neutral proteinase. Proc. Natl. Acad. Sci. USA. 78:210-214.

10. Smedley, L. A., M. G. Tommesen, R. A. Sandhaus, C. Haslett, L. A. Guthrie, R. B. Johnston, P. M. Henson, and G. S. Worthen. 1986. Neutrophil-mediated injury to endothelial cells. Enhancement by endotoxin and essential role of elastase. J. Clin. Invest. 77:12331243.

11. Clark, R. A., and S. J. Klebanoff. 1975. Neutrophil mediated tumor-cell cytotoxicity. Role of the peroxidase system. J. Exp. Med. 141:1442-1447.

12. Slivka, A., A. F. LoBuglio, and S. J. Weiss. 1980. A potential role for hypochlorous acid in granulocyte mediated tumor-cell toxicity. Blood. 55:347-350.

13. Foote, C. S., T. E. Goyne, and R. I. Lehrer. 1983. Assessment of chlorination by human neutrophils. Nature (Lond.). 301:715-716.

14. Weiss, S. J., P. Klein, A. Slivka, and M. Wei. 1982. Chlorination of taurine by human neutrophils. Evidence for hypochlorous acid generation. J. Clin. Invest. 70:1341-1349.

15. Klebanoff, S. J. 1968. Myeloperoxidase-halide-hydrogen peroxide antibacterial system. J. Bacteriol. 95:2131-2138.

16. Albrich, J. M., C. A. McCarthy, and J. K. Hurst. 1981. Biological re-activity of hypochlorous acid: Implications for microbicidal mechanisms of leukocytic myeloperoxidase. Proc. Natl. Acad. Sci. USA. 78:210-214.

17. Albrich, J. M., J. H. Gilbaugh, K. B. Callahan, and J. K. Hurst. 1986. Effects of the putative neutrophil-generated toxin, hypochlorous acid, on membrane permeability and transport systems of Escherichia coli. J. Clin. Invest. 78:177-184.

18. Rosen, H., and S. J. Klebanoff. 1985. Oxidation of microbial iron-sulfur centers by the myeloperoxidase- $\mathrm{H}_{2} \mathrm{O}_{2}$-halide antimicrobial system. Infect. Immun. 47:613-618. 
19. Rosen, H., R. M. Rakita, A. M. Walthersdorph, and S. J. Klebanoff. 1987. Myeloperoxidase-mediated damage to the succinate oxidase system of Escherichia coli. J. Biol. Chem. 242:15004-15010.

20. Fliss, H., H. Weissbach, and N. Brot. 1983. Oxidation of methionine residues in proteins of activated human neutrophils. Proc. Natl. Acad. Sci. USA. 80:7160-7164.

21. Thomas, E. 1979. Myeloperoxidase, hydrogen peroxide, chloride antimicrobial system: Nitrogen-chlorine derivatives of bacterial components in bactericidal action against Escherichia coli. Infect. Immun. 23:522-531.

22. Grisham, M. B., M. M. Jefferson, D. F. Melton, and E. L. Thomas. 1984. Chlorination of endogenous amines by isolated neutrophils. J. Biol. Chem. 259:10404-10413.

23. Grisham, M. B., M. M. Jefferson, and E. L. Thomas. 1984. Role of monochloramine in the oxidation of erythrocyte hemoglobin by stimulated neutrophils. J. Biol. Chem. 259:6766-6772.

24. Schraufstätter, I. U., P. A. Hyslop, J. H. Jackson, and C. G. Cochrane. 1988. Oxidant-induced DNA damage of target cells. J. Clin. Invest. 82:1040-1050.

25. Ellman, G. L. 1959. Tissue sulfhydryl groups. Arch. Biochem. Biophys. 82:70-77.

26. Schraufstätter, I. U., W. A. Halsey, P. A. Hyslop, and C. G. Cochrane. 1988. In vitro models for the study of oxidant-induced injury of cells in inflammation. Methods Enzymol. 163:328-339.

27. Thannhauser, T. W., Y. Konishi, and H. A. Scheraga. 1987. Analysis for disulfide bonds in peptides and proteins. Methods Enzy mol. 143:115-119.

28. Rothstein, A. 1970. Sulfhydryl groups in membrane structure and function. Curr. Top. Membr. Transp. 1:135-176.

29. Schraufstätter, I. U., D. B. Hinshaw, P. A. Hyslop, R. G. Spragg, and C. G. Cochrane. 1985. Glutathione cycle activity and pyridine nucleotide levels in oxidant-induced injury of cells. J. Clin. Invest. 76:1131-1139.

30. Davies, K. J. A., M. E. DelSignore, and S. W. Lim. 1987. Protein damage and degradation by oxygen radicals II. Modification of amino acids. J. Biol. Chem. 262:9902-9907.

31. Starke, P. E., C. N. Oliver, and E. R. Stadtman. 1987. Modification of hepatic proteins in rats exposed to high oxygen concentrations. FASEB (Fed. Am. Soc. Exp. Biol.) J. 1:36-39.

32. Hyslop, P. A., D. B. Hinshaw, W. A. Halsey, I. U. Schraufstätter, R. D. Sauerheber, R. G. Spragg, J. H. Jackson, and C. G. Cochrane. 1988. Mechanisms of oxidant-mediated cell injury. $J$. Biol. Chem. 263:1665-1675.

33. Hyslop, P. A., D. B. Hinshaw, I. U. Schraufstätter, L. A. Sklar, R. G. Spragg, and C. G. Cochrane. 1986. Intracellular calcium homeostasis during hydrogen peroxide injury to cultured P388D1 cells. $J$. Cell. Physiol. 129:356-366.

34. Negulescu, A., A. Minta, R. Y. Tsien, and T. E. Machem. 1989. Intracellular $\mathrm{Na}$-dependence of the parietal cell $\mathrm{Na} / \mathrm{K}$ ATPAse assessed with a fluorescent sodium indicator. FASEB (Fed. Am. Soc. Exp. Biol.) J. 3(3):1967. (Abstr.)

35. Chen, P. S., T. Y. Toribara, and H. Warner. 1956. Microdetermination of phosphorus. Anal. Chem. 28:1756-1758.

36. Schraufstätter, I. U., D. B. Hinshaw, P. A. Hyslop, L. A. Sklar, R. G. Spragg, and C. G. Cochrane. 1986. Oxidant injury of cells. DNA strand breaks activate polyadenosine-diphosphate-ribose polymerase and lead to depletion of nicotinamide adenine nucleotide. J. Clin. Invest. 77:1312-1320.

37. Pogolotti, A. L., and D. V. Santi. 1982. High performance liquid chromatography-ultraviolet analysis of intracellular nucleotides. Anal. Biochem. 116:335-345.

38. Thomas, E. L., M. B. Grisham, and M. M. Jefferson. 1986. Cytotoxicity of chloramines. Methods Enzymol. 132:585-593.

39. Beutler, E. 1984. Red Cell Metabolism. A Manual of Biochemical Methods. Grune \& Stratton, Inc., Orlando, FL.

40. Birnboim, H. C., and J. J. Jevcak. 1981. Fluorometric method for rapid detection of DNA strand breaks in human white blood cells produced by low doses of radiation. Cancer Res. 41:1889-1892.
41. Althaus, F. R., S. B. Lawrence, G. L. Sattler, and H. C. Pitot. 1982. ADP-ribosyltransferase activity in cultured hepatocytes: interactions with DNA repair. J. Biol. Chem. 257:5528-5535.

42. Thomas, E. L., M. B. Grisham, and M. M. Jefferson. 1986. Preparation and characterization of chloramines. Methods Enzymol. 132:569-585.

43. Stelmaszynska, T., and J. M. Zgliczynski. 1978. N-(2-oxoacyl)amino acids and nitriles as final products of dipeptide chlorination mediated by the myeloperoxidase $/ \mathrm{H}_{2} \mathrm{O}_{2} / \mathrm{C}_{1}$-system. Eur. J. Biochem. 92:301-308.

44. Van Steveninck, J., R. I. Weed, and A. Rothstein. 1965. Localization of erythrocyte membrane sulfhydryl groups essential for glucose transport. J. Gen. Physiol. 48:617-632.

45. Schoner, W., M. Hasselberg, and R. Kison. 1988. Irreversible and reversible modification of -SH-groups and effect on catalytic activity. Methods Enzymol. 156:302-312.

46. Adunyah, S. E., and W. A. Dean. 1986. Effects of sulfhydryl reagents and other inhibitors on $\mathrm{Ca}^{++}$transport and inositol triphosphate-induced $\mathrm{Ca}^{++}$release from human platelet membranes. J. Biol. Chem. 261:13071-13075.

47. Deves, R., and R. M. Krupka. 1978. Cytochalasin B and the kinetics of inhibition of biochemical transport. Biochem. Biophys. Acta. 510:339-348.

48. Lambert, I. H., L. O. Simonsen, and E. K. Hoffmann. 1984. Volume regulation in Ehrlich ascites tumour cells: pH sensitivity of the regulatory volume decrease and role of the $\mathrm{Ca}^{++}$dependent $\mathrm{K}^{+}$channel. Acta Physiol. Scand. 120:P50.

49. Shapiro, H. M., P. J. Natale, and L. A. Kamentsky. 1979. Estimation of membrane potential in individual lymphocytes by flow cytometry. Proc. Natl. Acad. Sci. USA. 76:5728-5730.

50. Lichtshtein, D., H. R. Kaback, and A. J. Blume. 1979. Use of a lipophilic cation for determination of membrane potential in neuroblastomaglioma hybrid cell suspensions. Proc. Natl. Acad. Sci. USA. 76:650-654.

51. Ottolenghi, A. 1959. Interaction of ascorbic acid and mitochondrial lipids. Arch. Biochem. Biophys. 79:355-361.

52. D'Amore, T., and T. C. Y. Lo. 1986. Hexose transport in L6 rat myoblasts. II. The effects of sulfhydryl reagents. J. Cell Physiol. 127:106-113.

53. Blumenthal, R., J. N. Weinstein, S. D. Sharrow, and P. Henkart. 1977. Liposome-lymphocyte interaction: Saturation sites for transfer and intracellular release of liposome contents. Proc. Natl. Acad. Sci. USA. 74:5603-5607.

54. Reglinski, J., S. Hoey, W. E. Smith, and R. D. Sturrock. 1988. Cellular response to oxidative stress at sulfhydryl groups receptor sites in the erythrocyte membrane. J. Biol. Chem. 263:12360-12366.

55. Hinshaw, D. B., L. A. Sklar, B. Bohl, I. U. Schraufstätter, P. A. Hyslop, M. W. Rossi, R. G. Spragg, and C. G. Cochrane. 1986. Cytoskeletal and morphologic impact of cellular oxidant injury. Am. J. Pathol. 123:1040-1050.

56. Learn, D. B., and E. L. Thomas. 1988. Inhibition of tumor cell glutamine uptake by isolated neutrophils. J. Clin. Invest. 82:789-796.

57. Bellomo, G., and S. Orrenius. 1985. Altered thiol and calcium homeostasis in oxidative hepatocellular injury. Hepatology. 5:876882.

58. Spragg, R. G., D. B. Hinshaw, P. A. Hyslop, I. U. Schraufstätter, and C. G. Cochrane. 1985. Alterations in adenine triphosphate and energy charge in cultured endothelial and P388D1 cells after oxidant injury. J. Clin. Invest. 76:1471-1476.

59. Halliwell, B., and J. M. Gutteridge. 1986. Oxygen free radicals and iron in relation to biology and medicine. Arch. Biochem. Biophys. 246:501-514.

60. Hebbel, R. P., O. Shalev, W. Foker, and B. H. Rank. 1986 Inhibition of erythrocyte $\mathrm{Ca}^{2+}$-ATPase by activated oxygen through thiol- and lipid-dependent mechanisms. Biochim. Biophys. Acta. 862:8-16. 